\title{
The Impact of Climate Change on Coffee (Coffea arabica L.) Production and Genetic Resources
}

\author{
Getachew WeldeMichael", Demelash Teferi \\ Jimma Agricultural Research Center, P.O. Box, 192, Jimma, Ethiopia \\ *Corresponding Author: Getachew WeldeMichael, Jimma Agricultural Research Center, P.O. Box, 192, \\ Jimma, Ethiopia
}

\begin{abstract}
Coffee is among the most important traded commodities and accounts for $1 \%$ of the total value of world trade. An estimated 25 million farmers worldwide depend on coffee for their source of revenue. Despite its importance for economy of many countries, coffee production and genetic resources are highly threatened by increasing temperature and precipitation that would occur as a result of climate change. Therefore, the objectives of this paper are to review the impact of climate change on coffee production and genetic resources and to suggest the possible mitigation and adaptation strategies to be followed. High temperature and erratic rainfall which resulted from climate change reduce coffee yield directly by affecting growth and development of the plant. It also encourages increased incidence of coffee insect pests and diseases and reduces the yield and quality of coffee indirectly. Besides, predictions from global circulation models suggested that the change in temperature and precipitation could affect the distribution of areas climatically suitable for Arabica coffee and consequently many regions would become unsuitable. Moreover, wild coffee and coffee germplasm accessions of Arabica coffee, which have been conserved under ex-situ field gene-bank of Ethiopia and many other countries, are also under a high risk of extinction. Due to these reasons, most of the world leading coffee producers will be highly affected in the future. Therefore, coffee growing countries should be conscious of the impact of the changing climatic variables on coffee production and genetic resources and apply the required mitigation and adaptation strategies.
\end{abstract}

Keywords: Coffee yield, climate change, gemplasm, mitigation and wild coffee

\section{INTRODUCTION}

Coffee, which is grown in more than 60 tropical countries on more than 11 million ha of land, is the most important commodity in the world market next to oil. It accounts for a significant proportion of the foreign currency earnings of many developing countries and the economies of many countries in Africa and South America depend on the revenue from coffee production for their stability and development. However, coffee farmers receive less than $5 \%$ of the retail value of a cup of coffee (Waller et al., 2007)

Despite its importance for a millions of people in the world, currently coffee production in the producing countries is constrained by several factors. Among the many factors that affect coffee growth and yield, temperature and rainfall conditions are the major ones.

The average global surface temperatures for 2081-2100 as compared to 1986-2005 is forecasted to increase by $0.3^{\circ} \mathrm{C}$ to $1.7^{\circ}, 1.1^{\circ} \mathrm{C}$ to $2.6^{\circ} \mathrm{C}, 1.4^{\circ} \mathrm{C}$ to $3.1^{\circ} \mathrm{C}, 2.6^{\circ} \mathrm{C}$ to $4.8^{\circ} \mathrm{C}$ under RCP 2.6, RCP 4.5, RCP 6.0 and RCP 8.5 scenarios, respectively (IPCC,2013). Climate change has many negative effects on coffee production. 10-20\% global crop yields are expected to decline by 2050 (IPCC, 2007). The effect will be much threatening for crops like coffee as it is the major source of income for many farmers in developing countries

Besides, climate change may also impact indirectly on coffee through effects on insect pests and diseases. Coffee leaf rust has been attacking Arabica coffee throughout the growing countries and it is the main threat to coffee directly resulting from climate change. Even though farmers preferred to grow coffee in highland areas to eliminate the attacks of their coffee from rust, due to the suitable condition created for the fungus due to climate change, coffee leaf rust is becoming prevalent at higher altitudes (Koebler, 2013). In addition, the insect, known as, the coffee berry borer, Hypothenemus hampei or H. hampei, is becoming the biggest pest to coffee plants (Jaramillo et al., 2009). 
Moreover, since Arabica coffee has specific temperature requirements, the smallest increases in temperature could cause widespread damage to coffee and consequently it could make devastating impact on coffee industry (Jaramillo et al., 2009). They have also warned that if climate change keeps on as the current trend, most of the current suitable areas for coffee production will encounter a severe reduction. Davies et al. (2012) also forecasted that wild Arabica coffee species, which is the source of many resistant gens, will face a strong challenges as a result of climate change and they have already reported that coffee wild species will be wiped out by the year 2080. Similarly, despite there are about 21,407 coffee Arabica germplasm accessions in the different ex-situ field gene banks of the world of which the majority is found in Ethiopia (Kufa, 2010), these huge coffee genetic resources are under high risk due to the climate change. Hence, it is imperative to look for immediate measures to identify appropriate conservation strategies against the possible impact of climate change on coffee genetic resources.

Due to the above facts, the sustainability of the coffee industry is expected to face serious problems in the future and even currently, a rising temperature is already exerting its effect in many coffee producing farmers (Baker and Haggar, 2007).

So, unless coordinated efforts have been exerted to save this valuable crop, the livelihoods of many coffee producing farmers and nations whose economy is mainly dependent on coffee are highly affected. Therefore, it is important to identify the impact of climate change on coffee yield, quality and genetic resources globally.

Hence, this review will focus on the impacts of climate change on coffee production and genetic resources. The review also covers the possible adaptation strategies to be followed and finally identifies gaps to be addressed in future research. The topics include: the impacts of climate change on coffee production, coffee disease and pest epidemic, projected shifts in coffee suitability area due to climate change, the impact of climate change on coffee genetic resources and climate change mitigation and adaptation strategies

\section{OVERVIEW ON CLIMATE CHANGE AND ITS IMPACT ON COFFEE (Coffea arabica L.)}

According to United Nation (1992) climate change is defined as a change of climate which resulted from human activity in addition to natural climate variability observed over comparable time periods. Agriculture and other anthropogenic activities resulted in green house gases (GHG) such as $\mathrm{CO}$, $\mathrm{CH} 4$, and $\mathrm{N} 2 \mathrm{O}$ and contributed for the rising global temperature. Deforestation and burning of fossil fuels have been contributing to the rise in global temperature for the last 200 years (Greenhouse Gas Working Group, 2010).

Being the majority of coffee is grown and produced in developing countries, it is agreed that coffee plants are at risk to climate change (Iscaro, 2014). In general, climate change has many negative impacts on coffee production, quality and genetic resources globally and the major impacts of climate change on coffee (Coffea arabica L.) production and genetic resources are discussed under this section.

\subsection{The Impacts of Climate Change on Coffee Production}

Akin to any other crops, coffee production is mainly limited by drought and unfavorable temperatures. The effect of rainfall and temperature are expected to be significant in many coffee producing areas for two major reasons, one being the recognized change in global climate and the other being coffee cultivation has spread to the marginal lands where these limitation constitute major restriction to coffee production (Damatta and Ramalho, 2006).

The optimum air temperature requirements for Coffea arabica is considered to be from 18 to $21{ }^{\circ} \mathrm{C}$ The (Barros, 1999). Extreme temperatures can considerably affect the productivity of Arabica coffee plants in many ways: The photosynthetic rate is reduced at temperatures above $25^{\circ} \mathrm{C}$ (Willson, 1985; Descroix and Snoeck, 2008). Exposure to temperatures greater than $30^{\circ} \mathrm{C}$ depresses growth and can result in abnormalities within the leaves, stems, flowers or plants, reducing coffee yields (Franco, 1958; DaMatta, 2004; Eakin et al., 2009). However, Arabica coffee would give reasonable yields in marginal areas with average temperatures as high as $24-25^{\circ} \mathrm{C}$ using selected varieties and intensive management practices (DaMatta, 2004)

In the study conducted to quantify the loss in coffee yields as a result of climate change in northern Tanzanian highlands, Craparo et al. (2015) reported that increasing night time temperature is the most 
important climatic element responsible for diminishing $C$. arabica yields. They have also forecasted that average coffee production will drop to $145 \mathrm{~kg}$ / ha by 2060 and many coffee producing areas with similar minimum temperature trends will be highly affected in the future

Generally, temperature above $23^{\circ} \mathrm{C}$, the development and maturation of coffee berries are hastened, often causing loss of coffee quality. In contrast, in regions with a mean annual air temperature below $18^{\circ} \mathrm{C}$, growth is highly restricted. Occurrence of frosts strongly limit the economic success of the crop and as a result of closure of the stomata and lessening physiological activities of the coffee plant, the process of photosynthesis becomes limited when water stress occurs (Camargo, 2010).

Violent rains interrupt coffee flowering, cause hail damage. The erratic rains will result in year round coffee flowering, causing harvesting difficult and forced the farmers to harvest small quantities continuously. Coffee diseases like coffee beery disease which requires high moisture for their development is highly favored by high precipitation caused by climate change. The coffee drying and processing activities will also highly affected by change of the rainy seasons

\subsection{The Impact of Climate Change on Coffee Disease and Insect Pest Epidemic}

Coffee is critically vital for the economy of many regions. Millions of people in developing world directly or indirectly dependent on coffee for their source of revenue (Gay et al.2006). However, the coffee crop is threatened by many pests due to climate change. Berry borers, coffee leaf rust, coffee berry disease, bacterial blight, nematodes, Antestia bug, coffee thrips, leaf miners are the major pests that can significantly reduce crop yields and quality .

\subsubsection{The impact of climate change on coffee disease}

Coffee leaf rust is one of the major coffee diseases that can cause considerable damage to coffee yield and quality. Bigirimana et al. (2012) conducted a survey in Rwanda to see the association between CLR severity and elevation and reported that coffee farms located at higher elevation had less CLR than those at lower elevation

However, Coffee leaf rust widespread at higher altitudes where the environmental condition were not suitable for the fungus and currently disease is moving up to high land mountain slope as a result of favorable condition created by climate change (Jassogne, 2013; Koebler, 2013). This finding exactly agreed with the work of Chala (2009) who suggested that the new rust race appeared and even the highly tolerant variety is affected by coffee rust when the climate changes.

Bacterial blight of coffee, also known as Elgon or Solai dieback, caused by Pseudomonas syringae pv garcae van Hall, is becoming an important pest in Sidama and Gedeo Zone of Southern Ethiopia regional State. The current survey result also revealed that a different level of the disease severity was observed in all released coffee cultivars at different locations of the regions (Demelash and Ashenafi, 2017)

\subsubsection{The Impact of Climate Change on Coffee Insect}

Coffee berry borer (Hypothenemus hampei (Ferrari), common to central Africa (Guathier, 2000). is the most important constraint of coffee production globally (Damon, 2000). Until very recently, coffee berry borer was found attacking and cause damage to coffee plantations only at elevation of below $1500 \mathrm{~m}$ (Agegnehu et al., 2015). However, due to the favorable environmental condition created for the pest as a result of the rising temperature in most coffee growing areas in the world, the insect is now widespread at higher elevation above $1500 \mathrm{~m}$. Jaramillo et al. (2009) reported that coffee berry borer, Hypothenemous hampei, is one of the major insects of coffee that feed on coffee berries. And Their research discovered that coffee berry borer has an exponential population growth of $8.5 \%$ for every $1^{\circ} \mathrm{C}$ temperature increase.

Jaramillo et al. (2011) forecasted the number of generation of coffee berry borer in East Africa in order to foresee threats and prioritize management measures of the pest under future emission scenarios and they reported that currently, about 1 to 4 generations are born each fruiting season. The prediction about future prevalence of the coffee berry borer revealed that the population increases will become more drastic in both scenarios and the pest is forecasted to worsen the current Coffea arabica producing areas of most of Eastern African countries

Despite the surveys conducted in Ethiopia in 1967 did not show any evidence of coffee berry borers as temperatures in the Ethiopian highland's coffee growing areas were not conducive for coffee berry 
borer, the surveys conduct in 2003 revealed that the coffee berry borer was prevalent in southwestern Ethiopia. This could happen due to favorable environment created for the pest as a result of the rising temperature. Therefore, this insect is a great challenge for struggling coffee industry and will have serious implications for $C$. arabica production and livelihoods in East Africa. Thus, it is imperative to develop coordinated long term plans for managing coffee berry borer.

Similarly, the survey was conducted to estimate severity of blotch leaf miner and Antestia bug in Southwest Ethiopia in 2015/16 and the result showed that 35.11 and $28.3 \%$ blotch leaf miner (Leucoptera caffiana) was recorded at Bebeka and Agaro, respectively. Besides, more than economic injury level was recorded for Antestia bug in Southwest Ethiopia per single tree (JARC, Entomology unpublished).

In a study conducted in Brazil to analyze changing climatic variable on nematodes (Meloidoygne incognita) and coffee leaf miner (Leucoptera coffeella), Ghini et al. (2008) reported that the damage of coffee plantation by these pests will be higher under the future scenarios as compared to regular climatic conditions. Therefore, considering the above mentioned facts, it can be concluded that higher temperatures will be one of the major the major challenges for coffee industries worldwide

\subsection{Projected Shifts in Coffee Suitability Area Due to Climate Change}

Scientists agreed that climate change will have a negative impact in all coffee producing countries. Some areas would lose suitability and thers would gain from the changing climatic variables. Few researchers predicted the future climatic suitability of Arabica coffee and all researchers reported that there is decline in coffee producing areas globally and this situation jeopardize coffee industry globally unless the necessary mitigation and adaptation strategies are taken.

For example, in the study conducted to forecast future suitability area of coffee in Brazil, Pinto and Assad (2008) reported that climate change would make coffee production in current potential producing areas /Southeast region of Brazil/ unfeasible and the author reported that by 2070 the coffee crop will migrate to the South region where it is not currently suitable for coffee production

Similarly, the study in eight East African courtiers by (Ridley, 2011) affirms climate change will affect future Coffea arabica suitability areas and according to the author, there is a consistent predicted decline in the number of optimal Arabica coffee growing locations in East Africa post 2020. By 2050, all optimal locations in Zambia disappear and there are no optimal locations in Uganda. The number of optimal sites in Rwanda and Burundi decline. By 2080, there is a decline in the number of suitable Arabica coffee producing locations in West Ethiopia.

The future global loss of Arabica coffee suitability area is also documented by Ovalle-Rivera et al. (2015) as follows: Mesoamerica, South American and African countries would confront an average decrease in the area suitable for Arabica coffee up to 30\%, 16-20\%, 9-25\%, respectively. They have also reported that Mexico (29\%) from Mesoamerica, Brazil (29\%) from South America and Uganda (25\%) and Tanzania (22\%) from Africa would lose substantial amount of currently suitable areas for coffee by 2050. According to the authors the majority of East African countries including Ethiopia would be least affected by the climate change, in the future. In pacific countries, India and Vietnam would experience a loss of suitability areas and be highly affected.

However, in contrast to the above findings, Moat et al. (2017) reported that unless significant intervention has been made, 39-59\% of the current coffee growing areas in Ethiopia would become unsuitable for coffee cultivation as a result of climate change.

Projection on suitable future coffee growing areas for two major coffee species ( $C$. arabica and $C$. canephora) has been started very recently and few researchers compared the future suitability area of these two important coffee species globally using different models based on different emission scenarios. In this regard, Magrach and Ghazoul (2015) reported that climate change will have disparate effects on the two major coffee species of coffee and most areas in the future will be suitable for Robusta coffee production as compared Arabica which has high demand in the world market

On contrary, Bunn (2015) reported that higher coffee suitability area will be lost for coffee Robusta than Arabica and for both coffee species and East Africa and the Pacific Island regions will not be highly affected by the changing climatic variables in the future

The findings of Bunn (2015) and Ridley (2011) which indicated that East African countries are least affected by climate change is in disagreement with the finding of Davis et al. (2012) who projected 
substantial reduction in climatically suitable area for indigenous Arabica coffee in Eastern Africa. Besides, the current findings of Bunn (2015) who reported that C. canephora will lose more current coffee suitable areas than Arabica contradicted with the finding of Magrach and Ghazoul (2015) who predicted that the Arabica will lose more suitability area than C. canephora and this difference comes probably from the differences in both the model used and area sampled for study.

In general, all studies indicated that there will be considerable loss of current coffee suitability area for $C$. arabica and canephora in the future. Although researchers used different models to predict the future coffee suitability areas, all studies showed that East African countries are less affected by changing the climatic variables. However, Brazil, the leading coffee exporter is highly affected by climate change. Therefore, coffee producers in all coffee producing countries are expected to apply climate change adaptation strategies to sustain coffee industry. Besides, all studies predicted coffee suitability areas using temperature and precipitation only and therefore, soil factors and other climatic variables which affect coffee suitability should be considered in their future studies.

\subsection{The Impact of Climate Change on Coffee Genetic Resources}

Despite the cultivated Arabica coffee is growing in many countries in Africa and Latin America, it is originated from Ethiopia and the wild relatives grow only in Ethiopia, Uganda, and Kenya. (Koebler, 2013). For many agricultural crops, wild species are the sources important gens for the improvement. Cognizant of this fact, Davis et al. (2012) forecasted the distribution of indigenous Arabica coffee in future. The result showed that a striking and profound reduction in the number of bioclimatic ally suitable localities for indigenous Arabica coffee. The authors reported that there will be a reduction of $65 \%$ of the currently suitable areas for Arabica coffee under the lower energy requirements scenario. However, under high emission scenarios there will be a reduction of $85 \%$ of the currently suitable areas for Arabica coffee by 2080.

Apart from wild coffee species, changing climatic variables which would occur as a result of climate change also affects the coffee germplasm accessions conserved in ex-situ field gene bank of different coffee research institutes globally. World's Plant Genetic Resources for Food and Agriculture (FAO, 1998) reported that 21087 coffee accessions have been conserved worldwide in the field gene banks of Costa Rica, Colombia, Brazil, Côte d'Ivoire, Cameroon, Ethiopia, Kenya, Tanzania, Madagascar, India and Indonesia. However, these accessions are under serious threat of genetic erosion as a result of climate change (Kufa, 2010). Hence, it is imperative to look for urgent actions to identify appropriate conservation strategies.

Moreover, semi forest, garden and even plantations coffee, being they are cultivated under the same bioclimatic envelop, will be highly affected by climate change effects and consequently, coffee genetic diversity is expected to diminish considerably in certain areas (Davis et al., 2012).

Therefore, it is essential and the need of the day to save the genetic resources found in wild, semi forest, garden coffee through collecting and preserving in areas found to be tolerant to climate change. Besides, utilization of these huge coffee genetic resources through genetic diversity studies using modem biotechnological tools has a paramount importance.

\section{SuggeSted Climate Change Mitigation ANd Adaptation Strategies}

Coffee production will face serious challenges in the future and consequently the future and the economies of many nations would greatly suffer due to their dependence on coffee exports. Therefore, to alleviate the damage on coffee, all producing countries should take the required measures. And, climate change mitigation and adaptation measures must be integrated in policies of coffee producing countries and must be applied in order to sustain the struggling coffee plant and some of the strategies are listed below

\subsection{Planting Coffee under Shade}

Coffee shade trees have the ability to reduce the sun's impact on the plants and create lower temperatures suitable for Arabica coffee. Jaramillo et al. (2011) reported that shade trees can cause a reduction in temperature by up to $4 c^{0}$. The extensive implementation of different coffee shade trees in Colombia and Ethiopia, the increase in the population of coffee beery borer could be about 34 percent lower than expected (Jaramillo et al., 2011). Moreover, according to Negasso et al. (2015) adverse environmental stresses such as high soil temperatures and low relative humidity can be improved with implementation of shade tress under coffee plant 
Many farmers believe that shaded systems will decrease yields, increase maintenance via pruning and increase humidity, which increases incidence of crop devastating fungal diseases such as, the coffee leaf rust (Samnegard, 2014; Martinati, 2008). However, shade can have a positive effect in ensuring sustainable coffee production and quality (Jha, 2014). As for an increased incidence of fungal disease due to increased humidity, other methods such as windbreaks can be used in combination with shade trees in order to decrease the impact of humidity. The increased in maintenance of coffee as a result of the pruning is compensated as pruning's are sold for firewood or used by the workers. Hence, the use of shade is vital and essential for mitigating the climate change impact on coffee.

\subsection{Close Spacing, Mulching and Irrigation}

Close spacing also reduce the stress against coffee plant and creates lower air temperatures inside the plantation as compared to the peripheral environment. Moreover, irrigation has also been the main practice important for establishment of coffee in marginal areas where the mean temperature is too high for growing Arabica coffee. The maintenance of mulch under coffee trees can also be used as good soil conservation practice and makes coffee production possible to the adverse climatic conditions by improving physical properties of the soil (Haggar and Schepp, 2012). Therefore, using close spacing, mulching and irrigation, it is possible to improve the physical properties of the soil, thereby enhancing the possibility of coffee cultivation under adverse climatic conditions.

\subsection{Development of Disease and Heat Tolerant Varieties}

To fight against the impact of climate change, the genetic improvement of coffee should focus on development of disease, insect pest and heat tolerant varieties. Planting pest resistant varieties reduce the yield reduction due to disease and pest and also reduce the environmental pollution due to usage of pesticides. In this line, according to the report of ICO (2009) effort is being made by the Instituto Agronômico de Campinas (IAC) to transfer important coffee characteristics (such as resistance to disease, insect, resistance to higher temperatures) from Robusta to Arabica coffee.

Besides, the hybrid coffee cultivars developed from traditional coffee varieties and wild Ethiopian coffee plants coffee by a coffee breeding program run by, CIRAD and PROMECAFE showed improved quality at low land areas and have greater adaptability to hotter drier climates. ( Baker \& Haggar, 2007).

\subsection{Changing the Location}

To alleviate to effects of the rising temperature, researchers suggested that coffee production areas should be moved to highland areas where temperatures are usually lower (Jaramillo et al., 2011; Davis et al., 2012). In the study by Moat et al. (2017), shifting coffee growing areas together with forest reestablishment and protection could make fourfold increase in suitable coffee producing areas in Ethiopia.

\subsection{Diversification}

Given the high dependence of coffee as monoculture, farmers are very vulnerable to climate risks like e.g. prolonged drought periods or devastating rainfall and storm. To reduce this risk and enhance the resilience of agricultural production system, option to diversify production and farmers' income should be identified. Diversification is the main tool that farmers have to reduce their individual farm risk.

\section{SUMMARY AND CONCLUSION}

Despite the importance of coffee for the livelihood of many people in the world, the production is constrained by many factors. Drought and adverse temperatures, which resulted from climate change, are among the major factors that affects coffee production. The erratic rains will cause the coffee farmers to harvest small quantities continuously. Expanded droughts can cause flower abortion. High temperatures and sunshine can cause premature ripening of the beans, which will have a harmful impact on yield and quality of coffee.

Besides, climate change is projected to increase incidence and severity of coffee pests and diseases. For example, coffee berry borer is one of the coffee insect pests that newly expanding fast. Similarly, coffee leaf rust, which is one of the major coffee diseases in coffee producing countries, was prevalent with warmer temperatures but it is now recorded to be moving up the in highland and cooler areas. Climate changes will also affect the distribution of species with presently occupied areas becoming 
unsuitable and new regions of climatic suitability emerging. Changes in these climatic variables over the next century will result in a decline in the number of optimal locations in major coffee producing and exporting countries in Mesoamerica, South America, Pacific islands and Africa. Besides, loss of genetic resources as result of climate change is also another threat that coffee is facing. More than 21000 coffee germplasm accessions conserved in ex-situ field gene bank of worldwide is under a high risk of extinction.

Therefore, to ensure coffee sustainability, producing countries will have to adapt farming practices to mitigate the effects of future climatic change. Generally, most of the literature revealed that climate change will jeopardize coffee production in the years to come. Although there are inconsistencies among the literatures it can be concluded that climate change will result in loss of coffee suitability area in the future. However, most of the predictions of future coffee suitability areas were carried out by considering precipitation and rainfall, despite areas conducive for coffee production is determined by many factors like soil type, humidity and soil water content etc. Besides, the number of models used to predict the future suitability area of coffee as result of climate change is different which makes the results inconsistent. Moreover, most of the studies conducted did not consider the suitability of these areas for coffee shade trees, as suitability of the areas for shade trees is also changing as climatic variables are changing in the future. Furthermore, the impact of climate change on coffee productivity is not quantified at regional or countries level despite coffee farmers are still experiencing the yield loss as result changing climatic variables.

\section{REFERENCES}

[1] Agegnehu E, Thakur A, Mulualem T (2015). Potential impact of climate change on dynamics of coffee berry borer (Hypothenemus hampi Ferrari) in Ethiopia. Open Access Library Journal. 2(1):1

[2] Baker P, Haggar J (2007). Global warming: the impact on global coffee. In SCAA conference handout. Long Beach, USA.

[3] Barros RS, Maestri M, Rena AB (1999). Physiology of growth and production of the coffee tree- a review. J. Cof. Res. 27(1): 1-54.

[4] Bigirimana J, Njoroge K, Gahakwa D, Phiri NA( 2012). Incidence and severity of coffee leaf rust and other coffee pests and diseases in Rwanda. Afr. J. Agri. Res. 7(26):3847-3852

[5] Bunn C (2015). Modeling the climate change impacts on global coffee production, Doctoral dissertation, Humboldt-Universität zu Berlin, Lebenswissenschaftliche Fakultät. pp.196

[6] Chala J (2009). Coffee leaf rust in forest populations and reaction of some collections to the disease in Southwest Ethiopia. Msc thesis, Haromayya University, pp. 107

[7] Camargo MBPD (2010). The impact of climatic variability and climate change on Arabica coffee crop in Brazil. Bragantia. 69(1): 239-247

[8] Craparo CW, Van Asten PJA, Läderach P, Jassogne LT, Grab SW (2015). Coffea arabica yields decline in Tanzania due to climate change: Global implications. Agric. For. Meteorol. 207:1-10.

[9] DaMatta FM (2004). Ecophysiological constraints on the production of shaded and unshaded coffee: A review. Field crops research. 86(2:99-114.

[10] DaMatta FM, Ramalho JDC (2006). Impacts of drought and temperature stress on coffee physiology and production: A review. Braz. J. Plant Physi. 18(1):55-81.

[11] Damon A (2000). A review of the biology and control of the coffee berry borer, Hypothenemus hampei . Bulletin of entomological research. 90(6):453-465.

[12] Davis AP, Gole TW, Baena S, Moat J (2012). The impact of climate change on indigenous arabica coffee (Coffea arabica L.): Predicting future trends and identifying priorities. PLoS One. 7(11): p.e47981.

[13] Demelash T, Ashenafi A (2017). Assessment of commercially grown coffee types for their tolerance to bacterial blight of coffee (BBC) at Sidama and Gedeo Zones, Southern Ethiopia. Sky J. Agri. Res. 6(1):1-5

[14] Descroix F, Snoeck J (2008). Environmental factors suitable for coffee cultivation. Coffee: Growing, processing, sustainable production: A guidebook for growers, processors, traders and researchers: pp.164-177

[15] Eakin HC, Wehbe $\mathrm{MB}(2009)$. Linking local vulnerability to system sustainability in a resilience framework: Two cases from Latin America. Climatic change. 93 (3-4):355-377.

[16] FAO (Food and Agriculture Organization of the United Nations) (1998). State of the World's Plant genetic resources for food and agriculture. FAO, Rome. 510p.

[17] Franco CM (1958). Influence of temperature on growth of coffee plant. IBEC Research Institute.

[18] Gay C, Estrada F, Conde C, Eakin H, Villers L (2006). Potential impacts of climate change on agriculture: A case study of coffee production in Veracruz, Mexico. Climatic Change. 79(3-4):259-288. 
[19] Gauthier N (2010). Multiple cryptic genetic units in Hypothenemus hampei (Coleoptera: Scolytinae): Evidence from microsatellite and mitochondrial DNA sequence data. Bio. J. Linnean Soci. 101(1): 113-129

[20] Ghini R, Emília H, Mário JPJ, José AM, Renata RVG. 2008. Risk analysis of climate changeon coffee nematodes and leaf miner in Brazil. Pesquisa Agropecuária Brasileira. 43(2):187-194. https://dx.doi.org/10.1590/S0100-204X2008000200005

[21] Greenhouse Gas Working Group. 2010. Agriculture's role in greenhouse gas emissions \& capture. Greenhouse Gas Working Group Rep. ASA, CSSA, and SSSA, Madison, WI.

[22] Haggar J, Schepp K (2012). Coffee and climate change, desk study: Impact of climate change in four pilot countries of the coffee and climate initiative. In coffee and climate. University of Greenwich Hamburg.

[23] International Coffee Organization (ICO) (2009). Climate change and coffee. Report presented to the International Coffee Council 103rd session. 23-25 ${ }^{\text {th }}$ September 2009. London, UK.

[24] International coffee organization(ICO)(2015).Sustainability of coffee sector in Africa, International coffee council $114^{\text {th }}$ session, 2-6 march 2015 , London, United kingdom

[25] IPCC (2007) Summary for policymakers. In Climate Change 2007, published for the inter-governmental Panel on Climate Change. Cambridge: Cambridge University Press. pp 2-18.

[26] IPCC (2013). Summary for Policymakers. In: Climate Change 2013: The Physical Science Basis. Contribution of Working Group I to the Fifth Assessment Report of the Intergovernmental Panel on Climate Change [Stocker, T.F., D. Qin, G.-K. Plattner, M. Tignor, S. K. Allen, J. Boschung, A. Nauels, Y. Xia, V. Bex and P.M. Midgley (eds.)]. Cambridge University Press, Cambridge, United Kingdom and New York, NY, USA.

[27] Iscaro J (2014). The impact of climate change on coffee Production in Colombia and Ethiopia. Glob. Majo. E-Jour., p.33.

[28] Jaramillo J, Chabi-Olaye A, Kamonjo C, Jaramillo A, Vega FE, Poehling HM, Borgemeister C (2009). Thermal tolerance of the coffee berry borer (Hypothenemus hampei): predictions of climate change impact on a tropical insect pest. PLoS One: 4(8), p.e6487.

[29] Jaramillo J, Muchugu E, Vega FE, Davis A, Borgemeister C, Chabi-Olaye A (2011). Some like it hot: the influence and implications of climate change on coffee berry borer (Hypothenemus hampei) and coffee production in East Africa. PLoS One, 6(9): p.e24528.

[30] Jha S, Bacon CM, Philpott SM, Méndez VE, Läderach P, Rice RA (2014). Shade coffee: update on a disappearing refuge for biodiversity. Bio.Scie. 64(5): 416-428.

[31] Jassogne L, Lderach P, Van Asten P(2013). The impact of climate change on coffee in Uganda: Lessons from a case study in the Rwenzori Mountains. Oxfam policy and practice: Climate change and resilience. 9(1):51-66.

[32] Koebler,J(2013). Buzzkill? How climate change could eventually end coffee. US news.com, US news \& world report.

[33] Kufa T (2010). Environmental sustainability and coffee diversity in Africa. In ICO world coffee conference. pp. 26-28

[34] Martinati JC, Harakava R, Guzzo SD, Tsai SM (2008). The potential use of a silicon source as a component of an ecological management of coffee plants. J. pytopath. 156(7-8):458-463.

[35] Moat Justin, Williams Jenny, Baena Susana, Wilkinson Timothy, Gole Tadesse W, Challa Zeleke K, Demissew Sebsebe , Davis Aaron P (2017). Resilience potential of the Ethiopian coffee sector under climate change, Macmillan Publishers Limited, nature plants , 17081 (2017).

[36] Magrach A, Ghazoul J (2015). Climate and pest-driven geographic shifts in global coffee production: Implications for forest cover, biodiversity and carbon storage. Plos one 10(7): e0133071.doi:10.1371/journal.pone.0133071

[37] Negasso OI, Mulatu DW, Tamrat VG (2015). A study of the effects of shade on growth, production and quality of coffee (Coffea arabica L.) in Ethiopia. Inter. J. Agri. Sci. 5(5): 748-752

[38] Ovalle-Rivera O, Läderach P, Bunn C, Obersteiner M, Schroth G (2015). Projected shifts in Coffea arabica suitability among major global producing regions due to climate change. Plos One 10(4):e0124155

[39] Pinto HS, Assad ED (2008). Expected change in coffee production in Brazil In: Coffee and climate change. Impacts and options for adaption in Brazil, Guatemala, Tanzania and Vietnam, GIZ, 2012.

[40] Ridley FV (2011). The past and future climatic suitability of Arabica coffee (Coffea arabica L.) in East Africa, Durham theses, Durham University. Available at Durham E-Theses Online: http://etheses. dur.ac.uk/680/

[41] Samnegård U, Hambäck PA, Nemomissa S, Hylander K (2014). Dominance of the semi-wild honeybee as coffee pollinator across a gradient of shade-tree structure in 
[42] United Nations (1992). United nations framework convention on climate change. PP.13. In Waller, J.M, Bigger, M, Hillocks, R.J. (eds.) 2007. Coffee pests, diseases and their management. CABI.

[43] Willson KC (1985). Climate and soil. In:Clifford,M.N., Willson, K.C. (eds.). Coffee - Botany, Biochemistry and Production of Beans and Beverage, pp.97-107. Crom Helm, London

Citation: Getachew WeldeMichael, Demelash Teferi, "The Impact of Climate Change on Coffee (Coffea Arabica L.) Production and Genetic Resources" International Journal of Research Studies in Agricultural Sciences (IJRSAS), 2019; 5(11), pp. 26-34, http://dx.doi.org/10.20431/2454-6224.0511004

Copyright: (C) 2019 Authors. This is an open-access article distributed under the terms of the Creative Commons Attribution License, which permits unrestricted use, distribution, and reproduction in any medium, provided the original author and source are credited. 